\title{
Diversity and antimicrobial resistance of Salmonella enterica serovars in surface river water and sediment
}

\author{
Diversidade e resistência antimicrobiana de sorovares de Salmonella enterica em águas \\ superficiais de rios e sedimentos
}

\author{
Alan Savariz1 (ORCID 0000-0003-2541-6523), Roberto Degenhardt ${ }^{2}$ (ORCID 0000-0003-4637-7455), Raquel Rebelatto 3 (ORCID \\ 0000-0001-6196-715X), Sabrina Castilho Duarte ${ }^{3}$ (ORCID 0000-0002-3368-0351), Fernanda Maurer D'Agostini' ${ }^{2}$ (ORCID 0000- \\ 0002-1115-6153), Alessandra Farias Millezi ${ }^{1^{\star}}$ (ORCID 0000-0003-1485-1773) \\ ${ }^{1}$ Instituto Federal Catarinense, Concórdia, SC, Brasil. *Author for correspondence: alessandra.millezi@ifc.edu.br \\ ${ }^{2}$ Universidade do Oeste de Santa Catarina, Joaçaba, SC, Brasil. \\ ${ }^{3}$ Embrapa Suínos e Aves, Concórdia, SC, Brasil.
}

Submission: 12/07/2021 / Acceptance: 17/09/2021

\begin{abstract}
This study aimed to evaluate the contamination by Salmonella sp. in the Capinzal River, to determine the prevalent serovars, patterns of antimicrobial resistance, and the genetic relationships between the serovars identified. A total of 108 samples were collected from 2016 to 2018. The isolation of Salmonella spp. was conducted according to International Organization for Standardization (ISO) standards. The antimicrobial resistance profile of the Salmonella isolates was evaluated, and isolates were selected for serotyping and verification of genetic similarity using the Pulsed-Field Gel Electrophoresis (PFGE) Technique. Of the 108 samples collected, $35(32.4 \%)$ were positive for Salmonella; $17.2 \%$ of the isolates were from the rural area; and $88.6 \%$ were from the urban area. Salmonella was isolated from all collect points along the river, with a higher incidence at the beginning of the urban area, indicating that contamination starts in the rural area and intensifies in the urban area of the city. A percentage of $35.1 \%$ of the Salmonella isolates were resistant to at least two antibiotics, while $18.9 \%$ were considered multidrugresistant (resistant to at least two antibiotics of different classes). Seven serovars were distinguished from the serotyped isolates, with a prevalence rate of $23.5 \%$ for $S$. Infantis, $S$. Orion, and $S$. Javiana; $11.8 \%$ for S. Senfterberg, and $5.9 \%$ for $S$. Montevideo, S. Heidelberg, and S. enterica subsp. enterica (O: 6.8). The variability in specific restriction sites generated by PFGE resulted in 10 pulsotypes, separating mainly different serotypes.
\end{abstract}

KEYWORDS: enteropathogenic bacteria, serotypes, genetic relationships, PFGE.

\section{RESUMO}

O objetivo deste estudo foi avaliar a contaminação por Salmonella sp. no rio Capinzal, para determinar os sorovares prevalentes, padrões de resistência antimicrobiana e as relações genéticas entre os sorovares identificados. Um total de 108 amostras foram coletadas de 2016 a 2018. O isolamento de Salmonella spp. foi conduzido de acordo com os padrões da International Organization for Standardization (ISO). O perfil de resistência antimicrobiana dos isolados de Salmonella foi avaliado, e os isolados foram selecionados para sorotipagem e verificação de similaridade genética por meio da Técnica de Eletroforese em Gel de Campo Pulsado (PFGE). Das 108 amostras coletadas, 35 (32,4\%) foram positivas para Salmonella; $17,2 \%$ dos isolados eram da área rural; e $88,6 \%$ da área urbana. Salmonella foi isolada em todos os pontos de coleta ao longo do rio, com maior incidência no início da área urbana, indicando que a contaminação começa na área rural e se intensifica na área urbana da cidade. Um percentual de $35,1 \%$ dos isolados de Salmonella foram resistentes a pelo menos dois antibióticos, enquanto $18,9 \%$ foram considerados multirresistentes (resistentes a pelo menos dois antibióticos de classes diferentes). Sete sorovares foram diferenciados dos isolados sorotipados, com uma taxa de prevalência de $23,5 \%$ para $S$. Infantis, $S$. Orion e $S$. Javiana; $11,8 \%$ para $S$. Senfterberg e 5,9\% para $S$. Montevidéu, $S$. Heidelberg e $S$. enterica subsp. enterica $(0: 6,8)$. A variabilidade em locais de restrição específicos gerados por PFGE resultou em 10 pulsotipos, separando principalmente diferentes sorotipos.

PALAVRAS-CHAVE: bactérias enteropatogênicas, sorotipos, relações genéticas, PFGE. 


\section{INTRODUCTION}

Salmonella is a genus of enteropathogenic bacteria responsible for serious food poisoning. Salmonellosis is recognized as one of the most important zoonosis in the world. This illness has been identified as an agent that causes outbreaks in many countries with significant endemicity and substantial morbidity. Additionally, salmonellosis has proven difficult to adopt ways to control its spread HALEY et al. (2009).

Released into rivers, Salmonella can survive for long periods of time. Also, Salmonella can be transported over long distances, transforming aquatic ecosystems in reservoirs of the pathogen. Evidence indicates that sediment may support long-term survival and persistence for Escherichia coli $0157: \mathrm{H} 7$ (BENJAMIN et al. 2013) and Salmonella (BENJAMIN et al. 2013, GORSKI et al. 2011). Combined with the widespread use of water resources, these conditions facilitate the transmission of Salmonella to humans and other animals. However, the survival and persistence of Salmonella in water depend on several environmental factors. The environmental health of rivers is closely related to how these resources are used, mainly through the proper manure management from agricultural production and the treatment of urban effluents (MARCHESAN \& FRAGA 2014).

Agricultural activities can be responsible for environmental problems due to the large amount of waste produced. Some producers consider the use of animal manure as an important biofertilizer for crops. Importantly, when animal manure is used as a crop biofertilizer, proper treatment of the animal manure must take place to avoid the transmission of pathogens. The improper handling of these by-products can contaminate soil and water bodies and compromise the production chain. For example, studies have shown that the surface water contamination in West of Santa Catarina State is caused by thermotolerant coliforms and Salmonella (ROHDEN et al. 2009, STERZ et al. 2011, FALAVINHA \& DEGENHARDT, 2014).

There are difficulties in controlling Salmonella spp. in poultry farms in Brazil, as some serotypes do not impact productivity. Therefore, besides eradication, reduced programs are often costly and complex. Currently, vaccines are used as an alternative to control the transmission of some Salmonella serotypes, such as Salmonella Enteritidis. However, the exacerbated use of antimicrobials, both in the animal production chain and the human population, increases the selective pressure and leads to the selection of resistant enterobacterial strains. Thus, when resistant enterobacterial strains contaminate rivers, it can spread to different niches. In addition, in cases of bacterial infections, acquired resistance may make it difficult to treat patients undergoing antimicrobial treatment (PALHARES et al. 2014).

In Brazil, there are few studies on the presence of Salmonella in aquatic environments. However, in other countries, the presence of Salmonella serotypes with clinical importance in natural waters has been well documented (HALEY et al. 2009). Furthermore, the presence of coliforms is checked in most limnological studies, and it is considered a fast and straightforward method once it indicates the presence of pathogens (ROHDEN et al. 2009). Therefore, due to the issue's relevance, this study aimed to determine the prevalence of Salmonella serovars in the Capinzal River, patterns of antimicrobial resistance, and the genetic relationships between the serovars identified.

\section{MATERIAL AND METHODS}

\section{Characterization of the collecting area}

The Capinzal River source is located community of São Roque, a rural area of Capinzal, in the midwest region of Santa Catarina, Brazil. Fragments of riparian forest are found at the source of the Capinzal River. This area is characterized by places of lotic waters, rapids, waterfalls, and places of lentic waters located in a valley, a characteristic that favors the transport of organic matter and sediment to the water body. From the source to its mouth, at the Rio do Peixe, the Capinzal River is approximately $8.5 \mathrm{~km}$ measured in a straight line.

The river runs through the countryside and the urban area, receiving a lot of effluents throughout its course. The Capinzal River has been used in many agricultural activities such as animal feeding. Thus, it is possible to observe intense poultry activity around the river. The main problem is the use of untreated aviary beds as biofertilizers for fertilizing dams and crops.

\section{Sampling design}

Samples ( $n=108$ ) were collected between February to October 2016 (four data collecting periods) and February to November 2018 (five data collecting periods). Six collecting points were chosen along the route of the Capinzal River - SC (from the source to near the mouth), three points in the rural area (points A, B, and $\mathrm{C}$ ), and three in the urban area (points $\mathrm{D}, \mathrm{E}$ and F). Of the 108 samples, 54 were collected in the rural area and 54 in the urban area, and from each area, there were 27 water and 27 sediment samples, totaling 
54 water and 54 sediment samples.

\section{Sample collecting}

Water samples were collected using sterile gauze, tied by a line, and immersed for 24 hours in the water body, performing the water filtration, as described by QUINN et al. (1995). Subsequently, the gauze was stored in sterile plastic bags. The sediment samples from the water body were collected using sterile plastic bottles. They were then immersed in the water with the mouth down until reaching the bottom of the river. The excavation was carried out with the edge of the bottle, and then the bottle was capped. The samples were transported, at room temperature, to the Microbiology and Immunology Laboratory of UNOESC Joaçaba, where the samples were processed up to 24 hours after collecting.

\section{Salmonella spp isolation and identification}

Isolation was carried out following the ISO 6579: 2002 / Amd.1: 2007 and ISO 6579-1: 2017 standards for the detection of Salmonella spp. (INTERNATIONAL ORGANIZATION FOR STANDARDIZATION 2007; 2017). Samples were transferred to a vial containing $230 \mathrm{~mL}$ of Buffered Peptone Water, shaken to release organic matter from the tissue, and incubated at $34 \stackrel{\circ}{\circ} \mathrm{C}-38{ }^{\circ} \mathrm{C} / 16$ to 18 hours. After that period, the samples constituted the pre-enriched cultures. For selective enrichment, two procedures were used. Procedure A: 0.1 $\mathrm{ml}$ of the pre-enriched cultures were transferred to Rappaport Vassiliadis - MSRV semi-solid medium plates. Plates were incubated at $42.5 \stackrel{\circ}{\circ} \mathrm{C} / 24-30$ hours in an air circulating incubator. After incubation, the presence of compatible colonies was observed. Procedure B: $1.0 \mathrm{ml}$ of the pre-enriched cultures were transferred to tubes with $10 \mathrm{ml}$ of Muller Kaufmann Tetrathionate Broth - MKTT. Tubes were incubated at $36.0+/ .1 .0 \stackrel{\circ}{\circ} /$ 24 - 30 hours. After incubation, isolation was performed. The isolation of 1 uL of the culture from the migration area in the MSRV and MKTT culture media was streaked on XLD agar and Bright Green (VB) agar. Plates were then incubated for 24 hours, at $36{ }^{\circ} \mathrm{C}$, to identify the typical morphology of colonies of Salmonella spp. Subsequently, the suspected colonies were subjected to confirmatory biochemical tests: TSI Agar; urea hydrolysis: L-Lysine decarboxylation; Detection of $\beta$-galactosidase; Voges-Proskauer reaction; indole reaction (ISO 6579:2002; ISO 6579-1:2017). One isolate was selected from each collecting point and period. Isolates were serotyped at the National Reference Center, Osvaldo Cruz Institute, Rio de Janeiro, Brazil, using a standard slide agglutination assay according to the scheme of Kauffmann-White (BRASIL et al. 2011).

\section{Antimicrobial susceptibility testing}

An antibiogram of all isolated Salmonella samples was performed. The test was performed using the agar dilution method, as recommended by the CLSI (2017). For the cultures isolated in 2016 and 2018, 12 antimicrobials belonging to five classes were tested: Amikacin $(30 \mu \mathrm{g})$, Amoxicillin + Clavulanic acid $(30 \mu \mathrm{g})$, Ampicillin $(10 \mu \mathrm{g})$, Cephalotin $(30 \mu \mathrm{g})$, Cefepime $(30 \mu \mathrm{g})$, Cefoxitin $(30 \mu \mathrm{g})$, Ceftazidime $(30 \mu \mathrm{g})$, Cefuroxime $(30 \mu \mathrm{g})$, Ciprofloxacin $(5 \mu \mathrm{g})$, Gentamicin $(10 \mu \mathrm{g})$, Meropenem $(10 \mu \mathrm{g})$ and Sulfamethoxazole + Trimethoprim $(25 \mu \mathrm{g})$. For the isolated cultures in 2018, 15 antimicrobial agents belonging to eight classes were tested: Amikacin $(30 \mu \mathrm{g})$, Amoxicillin + Clavulanic acid $(30 \mu \mathrm{g})$, Ampicillin $(10 \mu \mathrm{g})$, Aztreonam $(30 \mu \mathrm{g})$, Cefazolin $(30$ $\mu \mathrm{g})$, Cefepime $(30 \mu \mathrm{g})$, Cefoxitin $(30 \mu \mathrm{g})$, Ceftazidime $(30 \mu \mathrm{g})$, Ceftriaxone $(30 \mu \mathrm{g})$, Ciprofloxacin $(5 \mu \mathrm{g})$, Chloramphenicol $(30 \mu \mathrm{g})$, Gentamicin $(10 \mu \mathrm{g})$, Meropenem $(10 \mu \mathrm{g})$ Sulfamimethoxazole $(25 \mu \mathrm{g})$ and Tetracycline $(30 \mu \mathrm{g})$.

\section{Pulsed-field gel electrophoresis (PFGE)}

According to the serotyped Samonella isolates, characterization was also performed using the Pulsed-Field Gel Electrophoresis (PFGE) Technique from the protocol described on Centers for Disease Control and Prevention (2017). For extraction of genomic DNA, cultures of Salmonella strains cultivated in Trypticase Soy Agar (TSA) were harvested by saline solution and standardized in the tube 2 of the MacFarland scale. Agarose buffers were produced with a mixture of $400 \mu \mathrm{L}$ of low melting point agarose at $2.7 \%$ (Low Melting / BioRad agarose), $400 \mu \mathrm{L}$ of cell suspension, and $20 \mu \mathrm{L}$ ( $20 \mathrm{mg} / \mathrm{mL}$ ) of proteinase $\mathrm{K}$ (Thermo Scientific). Buffers were incubated in $5 \mathrm{~mL}$ of lysis buffer $(1 \mathrm{M}$ Tris- $\mathrm{HCl}, 0.5 \mathrm{M}$ EDTA, $10 \%$ lauryl sarcosine, and $25 \mu \mathrm{L}$ of proteinase $\mathrm{K}[20 \mathrm{mg} / \mathrm{mL}]$ ) at $54^{\circ} \mathrm{C}$ for 2 hours, under shaking agitation. Cells were washed twice with Milli $Q$ water and 4 times with TE _ elution buffer ( $1 \mathrm{M}$ Tris-HCl, $0.5 \mathrm{M} \mathrm{EDTA})$ at $50{ }^{\circ} \mathrm{C}$ for 10 minutes, under agitation, and stored in TE solution at $4 \stackrel{\circ}{\circ}$. According to the manufacturer's instructions, the digestion of endonuclease restriction was performed with $50 \mathrm{U} /$ Xbal enzyme buffer (Thermo Scientific тм). Fragments were placed on 1.2\% agarose gel (BioRad) and submitted to Pulsed-Field Electrophoresis using the CHEF-DR III system (Bio-Rad). Parameters used were: 22 hours of running time; at a temperature of $14{ }^{\circ} \mathrm{C}$; low MW $50 \mathrm{~kb}$; high MW of $400 \mathrm{~kb}$; $6 \mathrm{~V} / \mathrm{cm}$ of voltage gradient; $120^{\circ}$ angle included with 6.76 seconds of pulse time; and 35.38 seconds of final pulse time. Electrophoresis was performed in 0.5 times 
TEB solution (Tris Base, Boric acid, and 0.5 M EDTA). Gels were stained with ethidium bromide (0.5 $\mu \mathrm{g} /$ $\mathrm{mL}$ ) for 30 minutes, and excess ethidium bromide was removed with three washes of 20 minutes each in distilled water. Afterward, gels were photographed under ultraviolet light. DNA digested from Salmonella enterica serotype Braenderup H9812 by the enzyme Xbal (Thermo Scientific) was used to determine the molecular weight.

\section{Analysis of results}

The data analysis relating to Salmonella enterica's isolation, antibiotic resistance profile, and serotyping was performed descriptively to indicate the presence or absence of the pathogen if the culture is resistant or sensitive, and the serovar. For the PFGE, the similarities between the profiles obtained were based on the comparison between the bands visualized on the gel and analyzed using the BioNumerics software (version 7.1; Applied Maths NV). Similarities between the fingerprint patterns of the isolates were determined based on the Dice correlation coefficient. The tolerance value of the band position was $1.7 \%$ (CDC, 2013). A dendrogram was generated by the Unweighted Pair Group Method with Arithmetic Mean (UPGMA), and the isolates were considered to have the same pulsotypes when the number and location of the bands were indistinguishable. Isolates with a band difference were supposed to have distinct pulsotypes.

\section{RESULTS AND DISCUSSION}

\section{Salmonella spp. isolation and identification}

Of the 108 samples collected, Salmonella was isolated from 35 samples (32.4\%), being 6/35 samples from the rural area (17.21\%), and $31 / 35$ from the urban area $(88.6 \%)$. Regarding the type of sampling of Salmonella isolates, 19/35 (54.3\%) came from sediment samples and 18/35 (51.4\%) from water samples. As for the collection period, 19/35 (54.3\%) isolates came from collections made in four periods in 2016 and $16 / 35$ (45.7\%) from collections made in five periods in 2018 (Box 1).

Box 1. Samples from different areas (urban and rural) of the Capinzal River on Santa Catarina in 2016 and 2018.

\begin{tabular}{|c|c|c|c|}
\hline Year/Seasons & Isolation Source & Area & Serovar \\
\hline 2016/summer & water & urban & Salmonella Infantis \\
\hline 2016/summer & sediment & urban & NS \\
\hline 2016/summer & water & urban & Salmonella Montevideo \\
\hline 2016/summer & sediment & urban & Salmonella Orion \\
\hline 2016/summer & sediment & urban & Salmonella Orion \\
\hline 2016/fall & water & urban & NS \\
\hline 2016/fall & water & urban & NS \\
\hline 2016/fall & sediment & urban & Salmonella Orion \\
\hline 2016/fall & sediment & rural & Salmonella Senftenber \\
\hline 2016/fall & water & urban & NS \\
\hline 2016/fall & water & urban & NS \\
\hline 2016/fall & sediment & urban & NS \\
\hline 2016/fall & water & urban & Salmonella Senftenber \\
\hline 2016/winter & sediment & rural & NS \\
\hline 2016/winter & water & urban & NS \\
\hline 2016/winter & sediment & urban & Salmonella Javiana \\
\hline 2018/summer & water & rural & Salmonella Javiana \\
\hline 2018/summer & water & urban & NS \\
\hline 2018/summer & sediment & urban & Salmonella Javiana \\
\hline 2018/winter & water & urban & NS \\
\hline 2018/winter & sediment & urban & NS \\
\hline 2018/winter & water & urban & Salmonella Heidelberg \\
\hline 2018/winter & sediment & urban & NS \\
\hline 2018/spring & sediment & urban & NS \\
\hline 2018/spring & water & urban & NS \\
\hline 2018/spring & water & urban & NS \\
\hline 2018/spring & water & urban & Salmonella Javiana \\
\hline 2018/spring & water & rural & Salmonella Infantis \\
\hline 2018/spring & water & rural & Salmonella Infantis \\
\hline 2018/spring & sediment & rural & NS \\
\hline 2018/spring & water & urban & NS \\
\hline
\end{tabular}




\begin{tabular}{|c|c|c|c|}
\hline \multicolumn{4}{|l|}{ Continuation... } \\
\hline 2018/spring & sediment & urban & Salmonella enterica subsp. Enterica $(0: 6,8)$ \\
\hline 2018/spring & water & urban & Salmonella Orion \\
\hline 2018/spring & sediment & urban & NS \\
\hline 2018/spring & water & urban & Salmonella Infantis \\
\hline
\end{tabular}

NS: Not serotyped.

The frequency of Salmonella isolation, from water and sediment, differed in the collections of points B, $C, D$, and $E$ - being equivalent at points $A$ and $F$. When comparing the percentages of isolation by sampling at the same collection points, the isolation in the sediment has always been equivalent or higher, except for point "D", which was more frequent in the water (Figure 1B)

Seven different serovars were found along the river, with four isolates $(23.5 \%)$ from $S$. Infantis (water sample), $S$. Orion (water and sediment samples), and $S$. Javiana (water and sediment samples); two isolates $(11.8 \%)$ from $S$. Senfterberg (water and sediment samples), and one isolate (5.9\%) from S. Montevideo (water sample), S. Heidelberg (water sample), and S. enterica subsp. enterica (O: 6.8) (sediment sample).

(A)

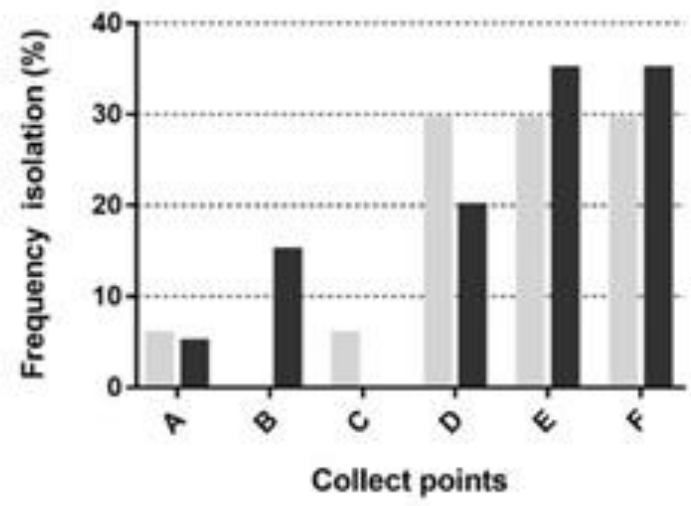

2016
(B)

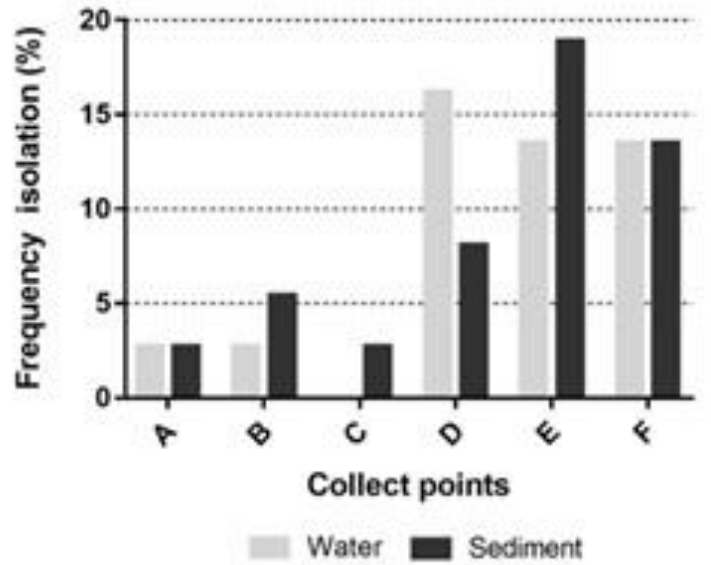

Figure 1. (A) Frequency of isolations by sampling point and year; (B) frequency of isolations comparing the types of samples.

\section{Antimicrobial susceptibility testing}

Only two Salmonella isolates obtained from collections performed in 2016 showed resistance, one resistant to Ampicillin and another to Cefoxitin and Meropenem. Of the isolates in 2018, 11 showed resistance to one or more antimicrobials, being: three isolates resistant to Gentamicin; one to Tetracycline; one to Cefoxitin and Meropenem and seven resistants to three or more classes of antimicrobials, being classified as multidrug-resistant according to SCHWARZ et al. (2010). The multi-resistant isolates showed the same resistance profile to Ampicillin, Sulfamethoxazole + Trimethoprim, Amoxicillin + Clavulanic acid, Tetracycline, and Chloramphenicol. Two isolates were resistant to all five antibiotics mentioned above and to Gentamicin (Table 1). No isolate showed resistance to Amikacin, Aztreonam, Cephalothin, Cefazolin, Cefepime, Ceftazidime, Ceftriaxone, Cefuroxime, and Ciprofloxacin.

Table 1. Salmonella resistance profile found in the study.

\begin{tabular}{ccccc}
\hline Resistance Profile & \multicolumn{2}{c}{ Number of antimicrobials resistance $^{\text {a }}$} & \multicolumn{2}{c}{ Serovars $^{\text {b }}$} \\
\cline { 2 - 5 } & Water & Sediment & Water & Sediment \\
\hline Amc & 4 & 3 & In, Or & En \\
Amp & 4 & 4 & In, Or & En \\
Cfo & 0 & 1 & $*$ & En \\
Clo & 4 & 3 & In, Or & En \\
Gen & 2 & 1 & Ja, En & En $(\mathrm{O}: 6,8)$ \\
Mer & 0 & 1 & * & En \\
Sxt & 4 & 3 & In, Or & En \\
Tet & 5 & 3 & In, Or,En & En
\end{tabular}

aAmoxicillin + Clavulanic acid (Amc), Ampicillin (Amp), (Cfo) Cefoxitin, Chloramphenicol (Clo), Gentamicin (Gen), Sulfametazol + Trimethoprim (Sxt), Meropenen (Mer), Tetracycline (Tet). ${ }^{\mathrm{b}} \mathrm{In}=$ Infantis, En $=$ Enterica, Ja $=$ Javiana Ori $=$ Orion. * No Salmonella persistence was detected. 


\section{Pulsed-field gel electrophoresis (PFGE)}

As shown in Figure 2, between the 17 isolates analyzed, ten distinct pulsotypes were obtained, with several bands ranging from ten to 14 and similarity between them from $86.4 \%$ to $59.3 \%$. The largest pulsotype (pulsotype 1 ) included five samples, being four isolated from $S$. Infantis and one from $S$. Orion. Pulsotype 1 had $86.4 \%$ similarity with pulsotype 2 ; these had $77.3 \%$ similarity with pulsotype 3 (S. Orion); $75.6 \%$ with pulsotype 4 (S. Orion), and $64.6 \%$ with pulsotype 5 formed by three isolates from $S$. Javiana. These five pulsotypes had $63.9 \%$ similarity with pulsotypes $6,7,8$, and 9 . Pulsotype 6 (S. Senftenberg) had $81.8 \%$ similarity to pulsotype 7 (S. Heidelberg); this had $71.1 \%$ similarity with pulsotype 8 (S. Senftenberg), and $67.4 \%$ with pulsotype 9 formed by isolates from S. Orion and S. Javiana. Pulsotypes 1 to 9 had $59.3 \%$ similarity with pulsotype 10 (S. Montevideo). Most samples of different serotypes were separated into different pulsotypes, and samples of the same serotype were grouped in the same pulsotype. Isolates of $S$. Infantis showed $100 \%$ homology with each other, and three of the four isolates of $S$. Javiana were also considered $100 \%$ homologous. However, the four isolates of $S$. Orion were separated into four distinct pulsotypes, with similarities ranging from $77.3 \%$ to $63.9 \%$. One of the isolates of S. Javiana showed $100 \%$ similarity with an isolate of $S$. Orion and only $63.9 \%$ similarity with the other three isolates of $S$. Javiana. Isolates of $S$. Senftenberg were also not grouped in the same pulsotype, with $71.1 \%$ homology.
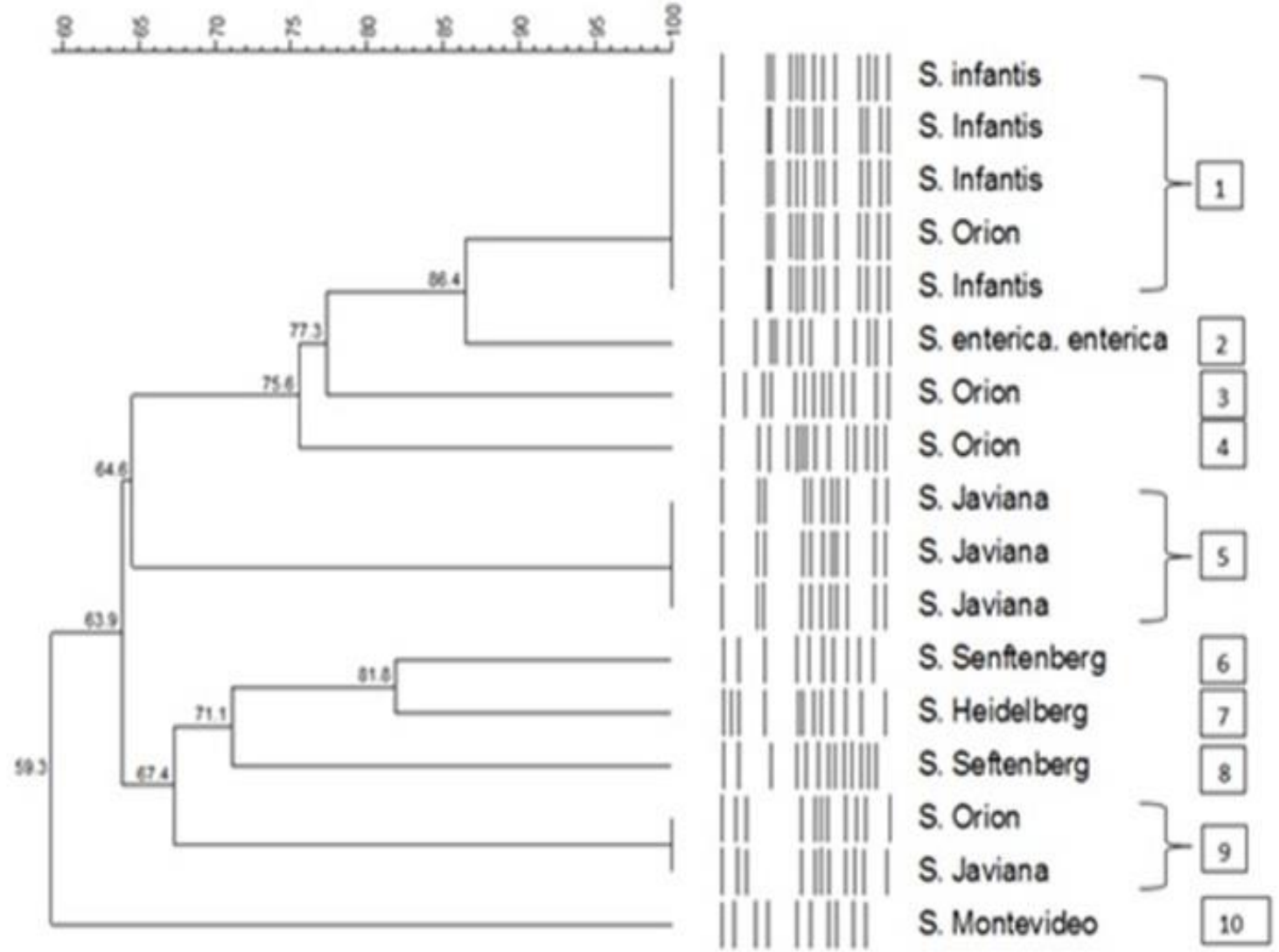

Figure 2. Dendrogram of the ten pulsotypes obtained by Pulsed-Field Gel Electrophoresis (PFGE).

The risk of contamination of the population with pathogenic bacteria, such as Salmonella, can compromise the animal production chain and the entire trophic chain. However, according to ČUČAK et al. (2018), although routine monitoring in human, meat production, and processing areas and animal meat is conducted, little is known about Salmonella persistence in environmental samples, such as ecological reservoirs. Aspects of how a given pathogen spreads as well as antibiotic resistance determinants are of great interest.

The Salmonella prevalence obtained in this study was 34.3\%. DEAVEN et al. (2021) analyzed freshwater samples from the Susquehanna River (USA), reported that Salmonella prevalence was 49\%, and increased river discharge was the main driver of Salmonella presence. MAURER et al. (2015) suggest that Salmonella strains persist in aquatic environments due to continuous contamination from animal sources and long-term persistence within these environments. Contamination of environmental waters with Salmonella may be of a greater public health concern than previously thought due to its ability to persist and grow 
outside of a host organism. This characteristic increases the probability of survival between hosts (WINFIELD \& GROISMAN 2003).

The environment, including surface waters, can be considered part of Salmonella's lifecycle, and, therefore, it influences the biogeographical patterns of these pathogens (MAURER et al. 2015). However, in the present study, although Salmonella was found throughout the entire river course, the isolation percentage was higher in the urban area due to greater proximity to homes, industries, and businesses. The contamination could begin in the rural area because there was the presence of the bacteria, but when entering the urban area, this contamination intensifies.

As for sampling, although the percentage of isolates from water (48.6\%) and sediment (51.4\%) were close, we had points with the equivalence of isolates and points with a considerable discrepancy. At point $D$, at the beginning of the urban perimeter, twice as much Salmonella was isolated from the water samples (concerning the sediment). At points B, C, and E, the isolation was higher in sediment samples, and at points $A$ and $F$, the isolation was equivalent. Such results are related to river flow and local climatic conditions. Patel et al. (2020) investigated the prevalence of antibiotic-resistant Salmonella spp. in the source waters of shrimp farms in the Nagapattinam region of South India, water and sediment samples were examined. The study indicated $28.7 \%$ of water and $25.5 \%$ of sediment isolates as Salmonella spp. According to HENNE et al. (2012), in lentic environments, the sediment allows isolating Salmonella more easily since calm waters favor sedimentation and deposition of pathogens to the bottom of the water body, along with organic matter. Such conditions permit the formation of a bacterial biofilm, which allows the persistence of contamination and makes the environment a source of infection with the pathogen. However, precipitation events, such as storms, can agitate the sediment and reintroduce strains of latent and persistent pathogens into the water column. In lotic environments, the movement of water washes and revolves around the sediment, indicating that the contamination may be recent due to the inadequate management of waste and effluents, probably from urban areas.

Between the isolates, 45.9\% were obtained from collections performed in 2016, and $54.1 \%$ from collections performed in 2018 , noting that there were four and five collection periods, respectively. In the different periods, an average of four isolates of Salmonella was obtained, except for November 2018, in which there were eight isolates. The temperature may have been an important factor for the increase in isolates in the period mentioned since studies such as those by HALEY et al. (2009) correlate the occurrence of the pathogen and the water temperature.

We had a variation of isolates at different collection points. At points $A, B$, and $C$, in the rural area, contamination is low. Point $A$ corresponds to the river's source and points $B$ and $C$ are in the rural area, where the river has already irrigated several rural properties, which use it for various agricultural activities, mainly poultry and pig farming. Despite this, the low contamination can be explained by the fact that they are places of lotic waters that favor the self-purification of the river, as observed by RAFAELI NETO et al. (2013) in the Caveira River, Santa Catarina Mountain Range. In urban areas, contamination intensifies. At the beginning of the urban area, Point $\mathrm{D}$ presented the highest frequency of Salmonella isolation in water samples. This shows that contamination is recent in this location since there is a transition area formed by forest remnants between the rural and the urban areas. This point receives a large load of effluents from the countryside and effluents from a district, with a large flow of trucks transporting animals at the top of the valley. In this place, studies have already identified the presence of multidrug-resistant Salmonella near a gas station, where these trucks are washed (RAFAELI NETO et al. 2013). This effluent resulting from the washing is discharged upstream of point $D$. The points "E" and " $F$ ", located in downtown city, presented the highest concentration of Salmonella in the sediment, characteristic of lentic water locations.

The presence of resistant and multi-resistant isolates to antimicrobials aggravates water use for recreational purposes or farming, such as irrigation of vegetables and animal feeding. Studies, such as those reported by WYATT et al. (1979), have already demonstrated the presence of the same multidrug-resistant pathogen in the water and in fish that live in the lagoons, inferring that the use of water without proper treatment represents a risk of contamination for the production chain and humans. There are countless studies on the resistance of Salmonella cultures to antimicrobials present in the human population and animal production. RIBEIRO et al. (2008) evaluated 79 strains of Salmonella isolated from samples of chickens and breeding environments and concluded that $81 \%$ were resistant to at least one of the tested antimicrobial agents. Some studies also evaluated the resistance profile of Salmonella in aquatic environments and treated effluents. For example, Ll et al. (2014) isolated 51 strains from ten irrigation ponds in the United States, and the susceptibility tests confirmed resistance to ampicillin, chloramphenicol, streptomycin, sulfamethoxazole, and tetracycline. 
When evaluating Salmonella's presence and resistance profile isolated from treated effluents in South Africa, the resistance profile to antimicrobials revealed that the strains of Salmonella spp. isolates were resistant to Sulfamethoxazole, Nalidixic Acid, and Streptomycin but susceptible to Quinolones and thirdgeneration Beta-Lactams (ODJADJARE \& OLANIRAN 2015). When evaluating the microbiological dangers associated with the agricultural use of urban rivers, it was concluded that they may represent risks to public health due to the great diversity of multidrug-resistant pathogenic enterobacteria isolated in urban water bodies. In rural and urban areas, the use of water without proper treatment for irrigating gardens and crops is a potential risk of transmission of resistant strains of Salmonella enterica to the population ODJADJARE \& OLANIRAN (2015). MICALLEF et al. (2012) evaluated the resistance profile of Salmonella cultures isolated from water used for tomato irrigation, and they found that the resistance to Sulfisoxazole was prevalent, and some resistance to Ampicillin, Cefoxitin, Amoxicillin/Clavulanic Acid, and Tetracycline was observed. In the present study, the presence of a multi-resistance profile repeated in different isolates may be related to the use of these antimicrobials and classes of antimicrobials in production and the urban area.

Bacterial resistance is still a worldwide problem. In more recent works, such as the one developed by PATEL et al. (2020), the Salmonella isolates were resistant to sulfonamide (SF) but sensitive to tetracycline (TC), chloramphenicol (CAP), and furazolidone (FZ). DÍAZ-TORRES et al. (2020) reported, overall, the highest detected antimicrobial resistance was toward colistin (73.68\%), followed by sulfamethoxazole (63.15\%), tetracycline $(57.89 \%)$, nalidixic acid $(52.63 \%)$, and trimethoprim $(52.63 \%)$.

Serovar diversity indicates that contamination occurs continuously and comes from different sources. The most common serovars identified were $S$. Infantis, $S$. Orion, and $S$. Javiana, followed by $S$. Senfterberg $S$. Montevideo, and $S$. Heidelberg. Among the points evaluated, point $F$, close to the mouth, presented a greater diversity of serovars: S. Infantis, S. Orion, S. Javiana, S. Seftemberg, and S. Heidelberg. At points A and B, there was a lower prevalence of Salmonella spp., and the serovars present were $S$. Infantis and Javiana. S. Infantis is among the ten most common related to isolation in farm animals in Europe (MICALLEF et al. 2012). Also, the authors report that, from the 1980s, serovar Infantis was widely isolated in cattle. It is important to point out that the collection point (source) is surrounded by pastures used for cattle breeding, and animals also use it for drinking, which may suggest an association of the presence of this serovar with the presence of cattle. Also, isolates of $S$. Infantis from point $B$ have the same resistance profile and genetic similarity using the PFGE Technique. DEAVEN et al. (2020), by means of sequencing, it detected 25 different Salmonella serovars. Also, according to these authors, on average, there were three serovars per sample, and $80 \%$ of Salmonella positive samples contained more than one serovar. Serovars give, Typhimurium, Thompson, and Infantis were identified.

In the other points (D, E, and $F$ ), in addition to the $S$. Infantis and $S$. Javiana serovars, the $S$. Senfterberg, $S$. Montevideo, and $S$. Heidelberg serovars were identified. The presence of $S$. Infantis in different collection points may indicate a positive influence of the aquatic environment on the survival of this serovar or contamination by it throughout the sampled course of the river.

Besides, the variability in specific restriction sites generated with PFGE resulted in ten pulsotypes, suggesting that isolated cultures of Salmonella are of phenotypes and possibly of different origins. The differences were mainly between different serovars. Genotypic comparison of the $S$. Infantis cultures isolated in this period indicates $100 \%$ similarity between the isolated cultures at the source and near the river's mouth. The S. Infantis culture isolated in January 2016 showed $100 \%$ similarity with the strains isolated in November 2018, suggesting that the contamination may be persistent or even that the origin is the same. The culture of $S$. Javiana isolated in the sediment of point $F$, in August 2016 , showed $100 \%$ similarity to $S$. Javiana culture isolated in the sediment of point $E$ in February 2018. Also, the culture of $S$. Orion isolated in February 2016, showed $100 \%$ similarity to $S$. Javiana culture isolated in 2018 , both at the point F. Similar results were observed by MAURER et al. (2015) when assessing Salmonella persistence in watersheds. The culture of S. Orion, $100 \%$ like the strains of $S$. Infantis, presented a resistance profile identical to one of the profiles presented by the strains of $S$. Infantis, and similar results were observed by LI et al. (2014). DÍASTORRES et al. (2020) also investigated the prevalence, serovar distribution, antimicrobial resistance, and pulsed-field gel electrophoresis (PFGE) typing of Salmonella enterica isolated from Lake Zapotlan, Jalisco, Mexico. Salmonella spp. were identified in 19 of $63(30.15 \%)$ samples. The predominant serotype identified was Agona (68.48\%), followed by Weltevreden (5.26\%), Typhimurium (5.26\%), and serogroup B (21.05\%). All Salmonella strains were genetically diverse, with a total of $11 \mathrm{Xbal}$ and four BInl profiles on PFGE.

All collection points along the river showed positive samples for Salmonella enterica. Also, the presence of isolates (18.9\%) multidrug-resistant to antimicrobials is a worrying factor concerning surface 
water contamination. The characteristics of the water body denote the reality of many rivers in Santa Catarina State and Brazil.

\section{CONCLUSION}

The Salmonella isolation from all collection points of the water body, combined with the variability of isolated serovars and the presence of multidrug-resistant strains, demonstrates potential contamination risks. Therefore, conducting continuous microbiological monitoring of water bodies is essential to understand surface water contamination processes by human activities. In addition, monitoring pathogenic bacteria is important to understand their transmission in the environment, the human population, and the animal production chain.

More studies are suggested to expand the knowledge about the microbiological impacts of anthropogenic activities in river environments and to assess the potential of contamination from different human and agricultural activities.

\section{ACKNOWLEDGEMENTS}

To the Instituto Federal Catarinense for the financial support of the project approved in announcement no 267/2017 Support for Integrated Education, Research, and Extension projects applied to the Local Production, Cultural, and Social Arrangements in the IFC Campuses. To Embrapa Swine and Poultry, the University of the West of Santa Catarina, Joaçaba Campus.

\section{REFERENCES}

BENJAMIN L et al. 2013. Occurrence of generic Escherichia coli, E. coli 0157 and Salmonella spp. in water and sediment from leafy green produce farms and streams on the Central California coast. International Journal of Food Microbiology 165: 65-76.

BRASIL et al. 2011. Manual técnico de diagnóstico laboratorial de Salmonella spp.: diagnóstico laboratorial do gênero Salmonella. Brasília: Ministério da Saúde.

CENTERS FOR DISEASE CONTROL AND PREVENTION. 2017. Standard Operating Procedure for PulseNet PFGE of Escherichia coli O157: H7, Escherichia coli non-O157 (STEC), Salmonella serotypes, Shigella sonnei and Shigella flexneri 157: 1-16. 2017.

ČUČAK D et al. 2018. Prevalence, Antibiotic Resistance and Diversity of Salmonella Isolates from Soils and Sediments in Serbia. International Journal of Environmental Research 12: 829-841.

DEAVEN AM et al. 2021. Salmonella Genomics and Population Analyses Reveal High Inter- and Intraserovar Diversity in Freshwater. Applied and Environmental Microbiology 87.

DÍAZ-TORRES O et al. 2020. Prevalence, Distribution, and Diversity of Salmonella Strains Isolated from a Subtropical Lake. Frontiers in Microbiology 11.

FALAVINHA G \& DEGENHARDT R. 2014. Qualidade Microbiológica da Água de Nascentes e Poços da Comunidade de Barro Branco, Capinzal, SC. Unoesc \& Ciência - ACBS 4: 209-216.

GORSKI L et al. 2011. Prevalence, distribution, and diversity of salmonella enterica in a major produce region of california. Applied and Environmental Microbiology 77: 2734-2748.

HALEY BJ et al. 2009. Distribution, diversity, and seasonality of waterborne salmonellae in a rural watershed. Applied and Environmental Microbiology 75: 1248-1255.

HENNE K et al. 2012. Analysis of structure and composition of bacterial core communities in mature drinking water biofilms and bulk water of a citywide network in Germany. Applied and Environmental Microbiology 78: 3530-3538.

INTERNATIONAL ORGANIZATION FOR STANDARDIZATION. ISO 6579:2002/AMD 1:2007 Microbiology of food and animal feeding stuffs - Horizontal method for the detection of Salmonella spp. - Amendment 1: Annex D: Detection of Salmonella spp. in animal faeces and in environmental samples from the primary production.

INTERNATIONAL ORGANIZATION FOR STANDARDIZATION. ISO 6579-1:2017 Microbiology of the food chain Horizontal method for the detection, enumeration and serotyping of Salmonella - Part 1: Detection of Salmonella spp.

LI B et al. 2014. Diversity and antimicrobial resistance of Salmonella enterica isolates from surface water in southeastern United States. Applied and Environmental Microbiology 80: 6355-6365.

MAURER JJ et al. 2015. Diversity and persistence of Salmonella enterica strains in rural landscapes in the southeastern United States. PLoS ONE 10.

MICALLEF SA et al. 2012. Occurrence and antibiotic resistance of multiple Salmonella serotypes recovered from water, sediment and soil on mid-Atlantic tomato farms. Environmental Research 114: 31-39.

ODJADJARE EC \& OLANIRAN AO. 2015. Prevalence of antimicrobial resistant and virulent Salmonella spp. in treated effluent and receiving aquatic milieu of wastewater treatment plants in Durban, South Africa. International Journal of Environmental Research and Public Health 12: 9692-9713.

PALHARES JCP et al. 2014. Salmonella and antimicrobial resistance in an animal-based agriculture river system. Science of the Total Environment 472: 654-661, 2014.

PATEL A et al. 2020. Prevalence of antibiotic resistant Salmonella spp. strains in shrimp farm source waters of 
Nagapattinam region in South India. Marine Pollution Bulletin 155.

RAFAELI NETO SL et al. 2013. Monitoramento da qualidade da água do Rio Caveiras no Planalto Serrano de Santa Catarina com suporte de tecnologias de geomática. Boletim Goiano de Geografia 33: 17-36.

RIBEIRO AR et al. 2008. Resistência antimicrobiana em Salmonella Enteritidis isoladas de amostras clínicas e ambientais de frangos de corte e matrizes pesadas. Arquivo Brasileiro de Medicina Veterinária e Zootecnia 60: 12591262.

QUINN PJ et al.1995. Clinical Veterinary Microbiology. London: Elsevier Health Sciences.

ROHDEN F et al. 2009. Microbiological monitoring of underground waters in cities of the Extreme West of Santa Catarina State. Ciência \& Saúde coletiva 14: 2199-2203.

SCHWAR S et al. 2010. Assessing the antimicrobial susceptibility of bacteria obtained from animals. Veterinary Microbiology 141: 1-4.

STERZ C et al. 2011. Análise microbiológica e avaliação de macroinvertebrados bentônicos como bioindicadores da qualidade da água do Riacho Capivara, município de Mondaí, SC. Unoesc \& Ciência 2: 7-16.

WINFIELD MD \& GROISMAN EA. 2003. Role of nonhost environments in the lifestyles of Salmonella and Escherichia coli. Applied and Environmental Microbiology. 69: 3687-3694.

WYATT LE et al. 1979. Occurrence and Control of Salmonella in Freshwater Catfish. Journal of Food Science: 44: 10671073. 